\title{
RESENHA
}

\section{O LYCEU DE GOIÁS E A FORMAÇÃO DA ELITE GOIANA}

Alessandra de Oliveira Santos ${ }^{1}$

BARROS, Fernanda. O tempo do Lyceu em Goiás: formação humanista e intelectuais (1906-1960). Jundiaí - S.P.: Paco, 2017.

Este livro O tempo do Lyceu em Goiás: formação humanista e intelectuais (19061960), incide sobre um objeto em um lugar bem específicos, propondo reconstruir o processo histórico do Lyceo de Goiás, no que diz respeito a formação humanista e intelectual dos jovens goianos. O pesquisador ou estudioso que atue no campo da história da educação brasileira e, especialmente, sobre a história da educação goiana, não poderá deixar de ler este livro da professora Fernanda Barros.

Doutora em educação pela Universidade Federal de Goiás, mestre em Educação pela Universidade Federal de Uberlândia, professora da Universidade Federal de Goiás Regional de Catalão, pesquisadora no campo da História da Educação, Fernanda centra sua discussão no processo de organização e estruturação do ensino secundário, em específico o Lyceu de Goias, com o firme proposito de revelar a forma com que os alunos do Lyceu eram formados a partir de um curriculo humanista e assim se tornarem parte da elite goiana.

Diante da importância do tema, a leitura da obra se torna impressindível a todos os pesquisadores envolvidos com o campo da História da Educação, pois a partir de uma variedade de fontes, a autora buscou compreender inúmeras questões em torno do Lyceu de Goias, principalmente nos aspectos relacionados a formação humanista e intelectual diante da perspectiva da elite goiana. O texto contém uma abordagem que relaciona o regional com o nacional e o internacional, apresentando de forma consequente e bem documentanda como se deu todo o processo educativo na constiuição do Lyceo no período proposto, em estreita relação com os aspectos culturais e políticos, com o

\footnotetext{
${ }^{1}$ Doutoranda do Programa de Pós-graduação em Educação da Faculdade de Educação - Universidade Federal de Goiás. Email: alesantosdp@yahoo.com.br
} 
propósito de ser uma instiuição destinada a certificar um público constituído pela elite local.

A obra se constituiu a partir de uma variedade de documentos como manuscritos, datilografados e impressos, atas do Lyceu, boletins informativos, relatórios, documentos da secretaria, regulamentos, periódicos, Leis, Resoluções, Portarias, dentre outros. Estes estão disponibilizados em locais como o Arquivo Histórico Estadual de Goiás, IPEHBC (Instituto de Pesquisas e Estudos Históricos do Brasil Central), IHGC (Instituto Histórico e Geográfico de Goiás, Núcleo de Referência Histórico das Escolas da Cidade de Goiás, e em páginas on line como IFE (Instituto Francês de Educação), Universidade de Lisboa, Faculdade de Direito no Insituto de História do Direito e do Pensamento Político, e no Brasil, em paginas da Câmara dos Deputados e do Senado - Biblioteca Digital, revelando uma metodologia tendo como base a pesquisa documental.

A partir das informações obtidas na documentação, a autora teve a pssibilidade de entender quais eram as pessoas, ocupantes de cargos como prefeitos, governadores, deputados, senadores, juizes, promotores, dentre outros, que foram alunos do Lyceu, sendo assim possível inferir sobre a constribuição da instituição na formação da intelectualidade goiana. $\mathrm{O}$ conceito de intelectual, foi assumido pela autora a partir das concepções de Antônio Gramsci, e o conceito de elite, a partir das idéias defendidas nas ciências sociais. A autora defende que em toda trajetória da insituição, é possivel perceber a intenção de se formar um intelectual em Goiás que fosse responsável pelas realizações políticas, sociais, econômicas, entre outras, a formação de uma intelectualidade goiana, que, formaria um grupo de elite, pensado, montado e financiado pelo governo local.

Para compreender toda essa trajetória do Lyceu de Goiás e como se deu a formação desse intelectual a autora organizou o livro em quatro capitulos. Nestes, vamos identificando as mudanças de currículo propostas pela legislação nacional e as particularidades detectadas na instituição.

Com o propósito de mostrar como foi criado o ensino secundário no Brasil, a autora inicia a obra mostrando como foram organizados estas instituições na Europa no século XIX. O capítulo intitulado A educação francesa levada ao cerrado: cópia e adaptação para a formação dos goianaos, faz uma retomada na história dos liceus a partir das Escolas Centrais na França, passando pelo liceu em Portugal até chegar no Brasil e especificamente na província de Goyaz com a criação do Lyceu de Goyaz em 1846. É 
possivel apreender, desde a França, que os liceus tinha como na sua excência e marca um curriculo humanista, permanecendo como insituição destinada à elite e com o objetivo de acesso ao ensino superior e para formação de profissionais liberais. Desta maneira, seguindo essencialmente o modelo francês a autora termina o capítulo mostrando os modelos abertos no Brasil sob o paradigama do Colégio Pedro II, bem como sob as determinações do Ato Adicional de 1834. Em Goiás, a autora destaca que desde sua criação, o Lyceu não sofre avanços consideráveis na sua estruturação, e um dos grandes entraves passa a ser as reformas localizadas e pontuais, deixando a escola sujeita ao vai e vem de normas.

Ao adentrar na República, a tão esperada equiparação chega ao Lyceu. A insituição passa a ser mais abrangente e mais proxima do que se esperava, afinal, o jovem se tornava Bacharel em Ciências e Letras, o que antes era apenas permitido aos alunos do Colégio Pedro II. Essa é a tônica do segundo capítulo, Lyceu de Goyaz: a instituição se organiza e faz jus à tradição 1906-1930, que retrata vince e cinco anos do Lyceu equiparado, tendo como referêncial um ensino propedêutico, humanista e com sua estrutura marcada pelas mudanças na legislação educacional propostas pelo governo federal, a fim de se chegar a um sistema organizado no Brasil, inserido em um contexto local cornelístico interessados em manter seu poder político. Desta forma, no decorrer do capítulo, a autora vai apresentando a consituição do Lyceu demonstrando o quanto ser formado pelo Lyceu atendia os interesses políticos locais, já que este aluno já concluia sua formação estando apto a ocupar cargos públicos compondo a máquina administrativa, fortalecendo o grupo político que estava no poder, e portanto, fazendo parte de um grupo social privilegiado.

No terceiro capítulo, O governo revolucionário em Goiás de 1930 a 1945: mudanças estruturais na educação e na formação da elite, vamos percebendo que as transformações políticas no Brasil dos anos de 1930 a 1945, promove mudanças substanciais na sociedade em vários aspectos, o que impacta diretamente no Lyceu. Os jovens que tinham acesso ao Lyceu mudam de perfil, afinal, o Lyceu de Goyaz se tornou Lyceu de Goiânia, e isso significava que os jovens goianos, estudantes da insituição, passam a ampliar, se diversificando, mas não deixando, segundo a autora, de ser a elite do Estado, que apenas ampliou em número e na origem. Foram anos de muitas mudanças, que inseriam o Estado no cenário econômico nacional, e com a criação do Ministério da Educação e Saúde ocorre uma reestruturação completa da ação do estado nos domínios 
da escolarização secundária e superior. Este período, fica marcado pelo dualismo do ensino secundário em propedêutico e profissionalizante, mas tendo o Lyceu de Goiânia como instituição que não deixou de atender o objetivo para o qual foi criada, fornecer uma educaçao humanista, preservada pela legislação, e com formação elitista e propedêutica.

O Lyceu de Goiânia nos anos em que a LDB estava em tramitação é o destaque do capítulo quatro, O ensino secundário e o Lyceu de Goiânia de 1946 a 1960, que nos apresenta o cenário vivivo pelas escolas goianas regidas por inúmeras portarias mudando um ou outro aspecto da educação secundaria enquanto aguardavam a LDB. Esses, são anos marcados por uma política populista, conturbados, que ocasionaram mudanças graduais na educação secundária e sua organização, revelando as tensões políticoeconômicas do país, que levaram a preservação da escola das elites em detrimento da escola das massas. Em termos de normatização, houveram algumas reformulações como: liberdade curricular, determinando que cada instituição pudesse oferecer as disciplinas que quiser desde que cumprido o currículo mínimo estabelecido, e regulamentação do numero de aulas. Ao Lyceu de Goiânia, a autora destaca que continuou usufruindo da situação de escola tradicional do estado, preservando-se como instituição centenária na formação dos intelectuais goianos. De toda forma, os alunos já faziam parte de uma nova classe que se desenvolvia em todo Brasil, aquela com origens econômicas e familiares diversas que tinham como preocupação a educação de seus filhos.

De forma bastante minuciosa, detalhada e cuidadosa, Fernanda Barros, revela neste livro o objetivo proposto, o de demonstrar, partir da trajetória do Lyceu de Goiaz, como esta instituição foi essencial na formação da elite e dos intelectuais de cunho tradicional, que por sua vez, foram responsáveis pela manutenção da ordem estabelecida no estado, em consonância com o contexto nacional, preservando a classe dominante em seu posto de poder, seja no poder político, ou no poder judiciário.

Recebido em: 11/01/2018

Aceito em: 01/03/2018 